\title{
KAJIAN KINERJA JALAN ADHYAKSA KOTA BANJARMASIN
}

\author{
Adhi Surya ${ }^{(1)}$ Muhammad Gunawan Perdana ${ }^{(2)}$ \\ (1), (2) Dosen Program Studi Teknik Sipil, Fatek, Universistas Islam Kalimantan MAB \\ Jalan Adhyaksa No.2, Banjarmasin, Kalimantan Selatan 70123 \\ E-mail: adhisurya1998@gmail.com/HP +6287782738533
}

\begin{abstract}
ABSTRAK
Sebagai Kota Metropolitan yang ke Sembilan, Banjarmasin mengalami pertumbuhan penduduk dan perkembangan ekonomi yang cukup pesat, maka seiring dengan hal tersebut Pemerintah Kota Banjarmasin merasa perlu untuk meningkatkan pelayanan bidang transportasi melalui kebijakannya dan menciptakan Kota Banjarmasin yang indah dan nyaman, dalam rangka mendukung fungsi kota sebagai pusat jasa dan bisnis dengan aktifitas perekonomian yang melayani sebagian regional wilayah kalimantan pada dua provinsi lainnya (Kaltim dan Kalteng). Jalan perlu dikembangkan sehingga dapat menjamin tersalurnya hasil produksi dari pusat-pusat produksi keluar wilayah melalui simpul-simpul distribusi utama. Kelengkapan jaringan jalan dalam arti khusus terbentuknya suatu jaringan secara hirarki baik arteri, kolektor maupun lokal lengkap dengan sistem yang teratur dengan baik merupakan syarat utama untuk mencapai efisiensi transportasi jalan raya. Ada satu genarator kuat di Jalan Adhyaksa yaitu kampus UNISKA MAB sebagai daya bangkit-tarik transportasi berupa roda dua dan roda empat. Sehingga pada waktu-waktu tertentu bisa terjadi penumpukan atau kemacetan akibat hambatan samping (kondisi parkir) dan pembuatan sistem satu arah jalur menuju Jalan Brigjen H.Hasan Basri dari Jalan Sultan Adam, Jalan Cemara Raya dan Jalan Cemara Ujung sehingga menambah beban lalu lintas Jalan Adhyaksa. Metodologi penelitian menggunakan penelitian deskriptif-kuantitatif yaitu melakukan survei volume lalu-lintas, kapasitas dan mengolah data volume lalu-lintas dengan microsoft excel untuk mendapatkan perhitungan Level of Service (LOS) atau Tingkat Pelayanan Ruas Jalan Adhyaksa berdasarkan MKJI 1997. LOS sebagai ukuran dari kinerja ruas jalan Adhyaksa.
\end{abstract}

Kata kunci : Ruas Jalan Adhyaksa, Volume Lalu Lintas, Kapasitas dan LOS 


\begin{abstract}
ABSTRACK
As the Ninth Metropolitan City, Banjarmasin experienced a rapid population growth and economic development, so along with that the Banjarmasin City Government felt the need to improve transportation services through its policies and create a beautiful and comfortable Banjarmasin City, in order to support the function of the city as a service and business center with economic activities serving a part of the Kalimantan region in two other provinces (East Kalimantan and Central Kalimantan). Roads need to be developed so as to ensure the distribution of production from production centers out of the region through the main distribution nodes. Completeness of the road network in the specific sense of the formation of a network in a hierarchical manner both arterial, collector and local complete with a wellorganized system is a key condition for achieving road transportation efficiency. There is one strong generator on Jalan Adhyaksa, namely the UNISKA MAB campus as a transportation power in the form of two wheels and four wheels. So that at certain times there can be a buildup or congestion due to side obstacles (parking conditions) and the creation of a one-way pathway to Jalan Brigjen H. Hasan Basri from Jalan Sultan Adam, Jalan Cemara Raya and Jalan Cemara Ujung, thereby increasing the traffic burden on Jalan Adhyaksa. The research methodology uses descriptive-quantitative research that is conducting a survey of traffic volume, capacity and processing traffic volume data with Microsoft Excel to get the calculation of Level of Service (LOS) or Adhyaksa Road Service Level based on MKJI 1997. LOS as a measure of performance Adhyaksa road segment.
\end{abstract}

Keywords: Adhyaksa Road Section, Traffic Volume, Capacity and LOS

\title{
PENDAHULUAN
}

\section{Latar Belakang}

Sebagai Kota Metropolitan yang ke Sembilan, Banjarmasin mengalami pertumbuhan penduduk dan perkembangan ekonomi yang cukup pesat, maka seiring dengan hal tersebut Pemerintah Kota Banjarmasin merasa perlu untuk meningkatkan pelayanan bidang transportasi dan menciptakan Kota Banjarmasin yang indah dan nyaman, dalam rangka mendukung fungsi kota sebagai pusat jasa dan bisnis dengan aktifitas perekonomian yang melayani sebagian regional wilayah kalimantan pada dua provinsi lainnya (Kaltim dan Kalteng). 
Dengan Memperhitungkan potensi yang besar dan keunikan kota Banjarmasin Sebagai Kota Seribu Sungai maka pembenahan jalan dan jembatan dalam kota merupakan kebutuhan yang tidak bisa ditunda, sehingga di peroleh sarana transportasi yang lebih baik, aman dan nyaman, sekaligus memenuhi standar pelayanan dan memperhatikan estetika dan keindahannya. Jalan perlu dikembangkan sehingga dapat menjamin tersalurnya hasil produksi dari pusat-pusat produksi keluar wilayah melalui simpul-simpul distribusi utama. Kelengkapan jaringan jalan dalam arti khusus terbentuknya suatu jaringan secara hirarki baik arteri, kolektor maupun lokal lengkap dengan sistem yang teratur dengan baik merupakan syarat utama untuk mencapai efisiensi transportasi jalan raya. Generator bangkitan-tarikan terbesar di ruas Jalan Adhyaksa adalah kegiatan kampus Universitas Islam Kalimantan Muhammad Arsyad Al Banjari pada saat jam-jam sibuk dan pembuatan sistem arah satu jalur menuju Jalan Brigjen H.Hasan Basri dari Jalan Sultan Adam, Jalan Cemara Raya dan Jalan Cemara Ujung menambah beban lalu lintas Jalan Adhyaksa

\section{Rumusan Masalah}

Penelitian ini akan melakukan survei lalu-lintas untuk mendapatkan volume lalu-lintas (kendaraan/jam) dalam 6 hari kerja. Volume lalu-lintas akan dibandingkan dengan dimensi geometrik jalan Adhyaksa untuk mendapatkan perbandingan (V/C) yang akan menyatakan LOS dari ruas jalan Adhyaksa. LOS adalah ukuran kinerja ruas Jalan yang dibakukan dengan peraturan dan pedoman MKJI 1997 (Manual Kapasitas Jalan Indonesia Tahun 1997). Ada pun identifikasi masalah sebagai berikut :

1. Adanya genarator bangkitan-tarikan dari kegiatan kampus Universitas Islam Kalimantan MAB baik dari roda dua dan roda empat.

2. Adanya pembuatan arah satu jalur arus transportasi yaitu :
a. Jalan Sultan Adam - Jalan Adhyaksa - Jalan Brigjen H. Hasan Basri
b. Jalan Cemara Raya - Jalan Adhyaksa - Jalan Brigjen H. Hasan Basri
c. Jalan Cemara Ujung - Jalan Adhyaksa - Jalan Brigjen H. Hasan Basri

Rumusan masalahnya adalah sebagai berikut :

1. Bagaimana volume lalu-lintas ruas Jalan Adhyaksa?

2. Bagaimana kapasitas ruas Jalan Adhyaksa?

3. Bagaimana Level of Service (LOS) atau Tingkat Pelayanan ruas Jalan Adhyaksa? 
JURNAL KACAPURI

JURNAL KEILMUAN TEKNIK SIPIL

Volume 3 Nomor 1 Edisi Juni 2020

\section{Tujuan Penelitian}

Penelitian ini bertujuan untuk mengetahui volume lalu-lintas, kapasitas jalan Adhyaksa dan Level of Service (LOS) untuk menentukan kinerja jalan Adhyaksa.

\section{Lokasi Penelitian}

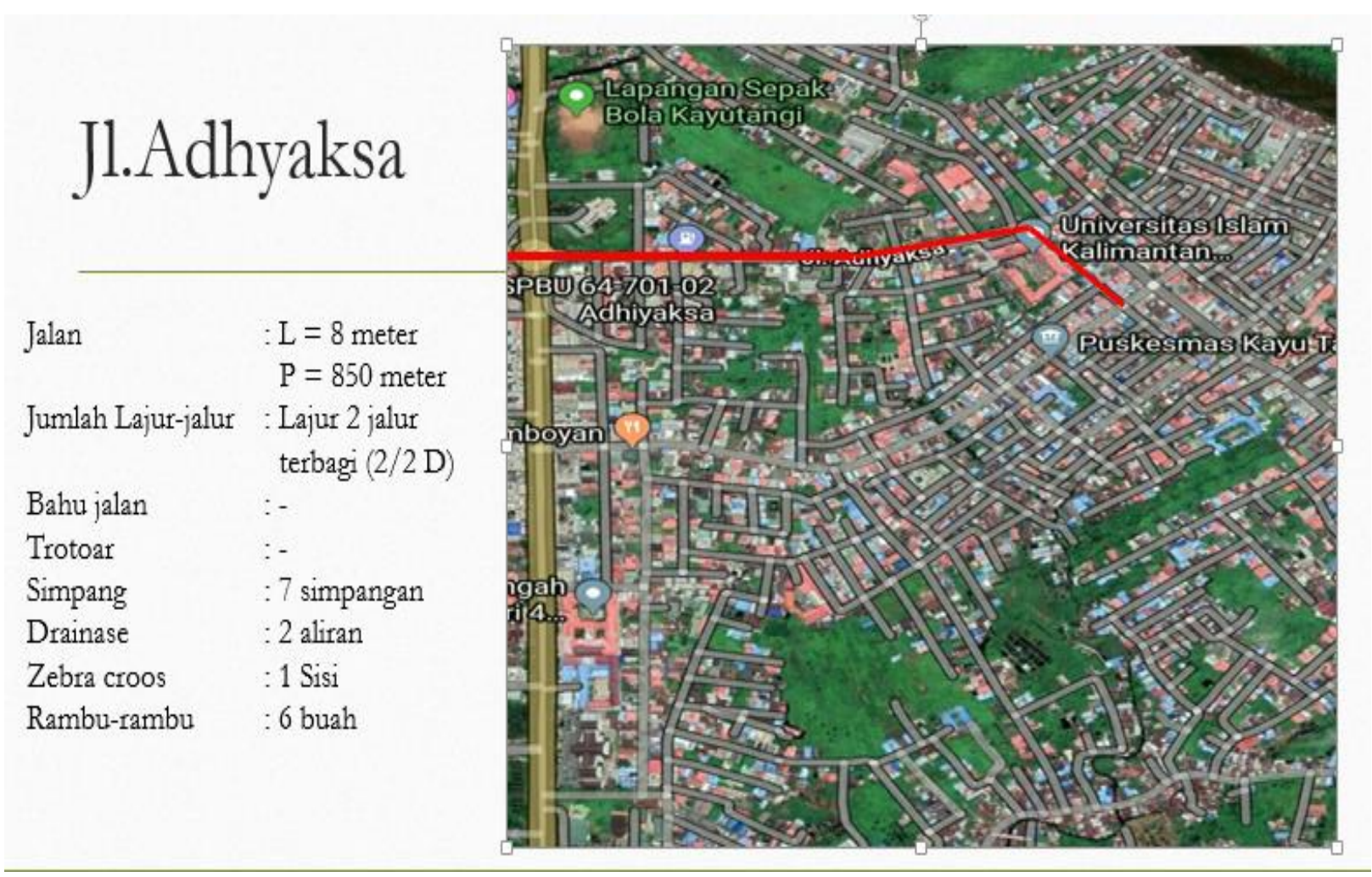

Gambar 1. Lokasi Penelitian Ruas Jalan Adhyaksa

Sumber : www.googlemap.com, 2020

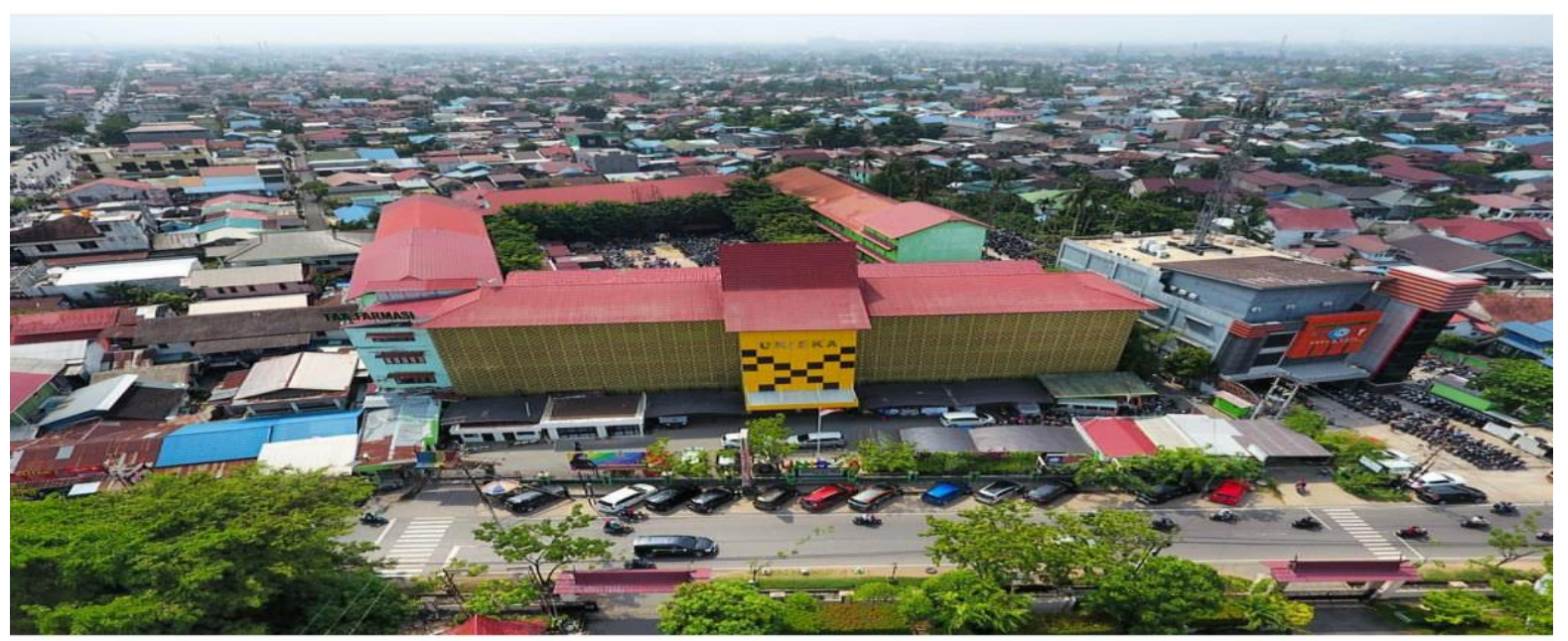

Gambar 2. Kampus UNISKA MAB Banjarmasin - Jalan Adhyaksa No.2 Sumber : koleksi pribadi dengan photo drone, 2020 


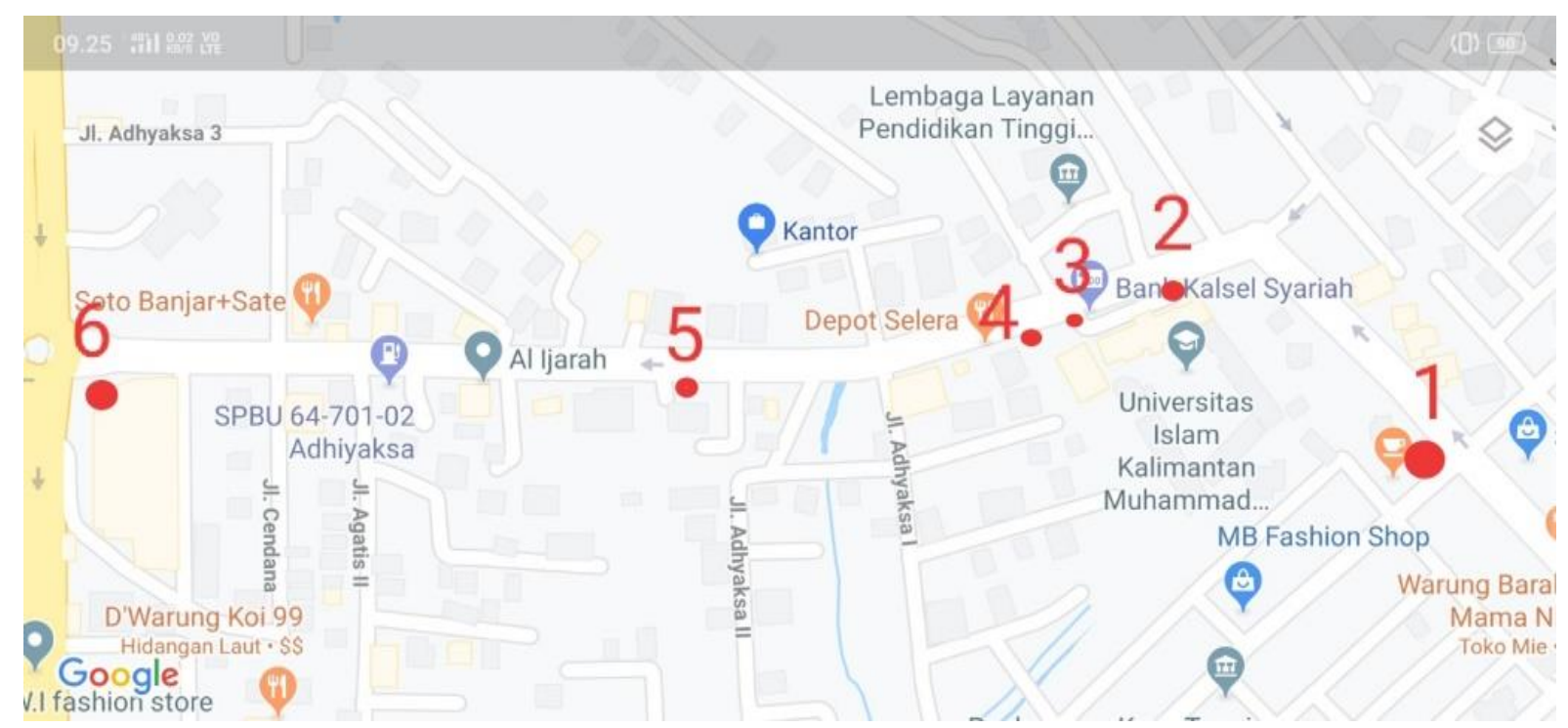

Gambar 3. Rute Survei Jalan Adhyaksa

Sumber : Analisis, 2020

Keterangan :

1. Ruas Jalan Adhyaksa dekat simpang 2. Depan Galeri UNISKA MAB empat Jalan Cemara Raya (Pos T1)

3. Depan Gerbang UNISKA MAB

5. Depan BANK KALSEL

4. Depan Gedung Fakultas Ekonomi UNISKA MAB

6. Ruas Jalan Adhyaksa dekat Bundara Kayu Tangi (Pos T2)

\section{TINJAUAN PUSTAKA}

\section{Pengertian Jalan}

Jalan merupakan akses yang sangat penting bagi masyarakat.jalan juga memiliki alat transportasi kendaraan yang meliputi berbagai segala bagian jalan, termasuk bangunan pelengkap yang di peruntuhkan bagi lalu lintas, jalan berada pada permukaan tanah, di atas permukaan tanah, di bawah permukaan air, terkecuali jalan kereta, jalan lori, dan jalan kabel. (UU No. 38 tahun 2004 tentang Jalan). Jalan umum adalah jalan yang diperuntukkan bagi lalulintas umum, jalan khusus adalah jalan yang dibangun oleh instansi, badan usaha, perseorangan, atau kelompok masyarakat untuk kepentingan sendiri. Bagian-bagian jalan meliputi ruang manfaat jalan, ruang milik jalan, dan ruang pengawasan jalan:

a. Ruang manfaat jalan meliputi badan jalan, saluran tepi jalan, dan ambang pengamannya.

b. Ruang milik jalan meliputi ruang manfaat jalan dan sejalur tanah tertentu diluar ruang manfaat jalan.

c. Ruang pengawasan jalan merupakan ruang tertentu diluar ruang milik jalan yang ada dibawah pengawasan penyelenggara jalan. 


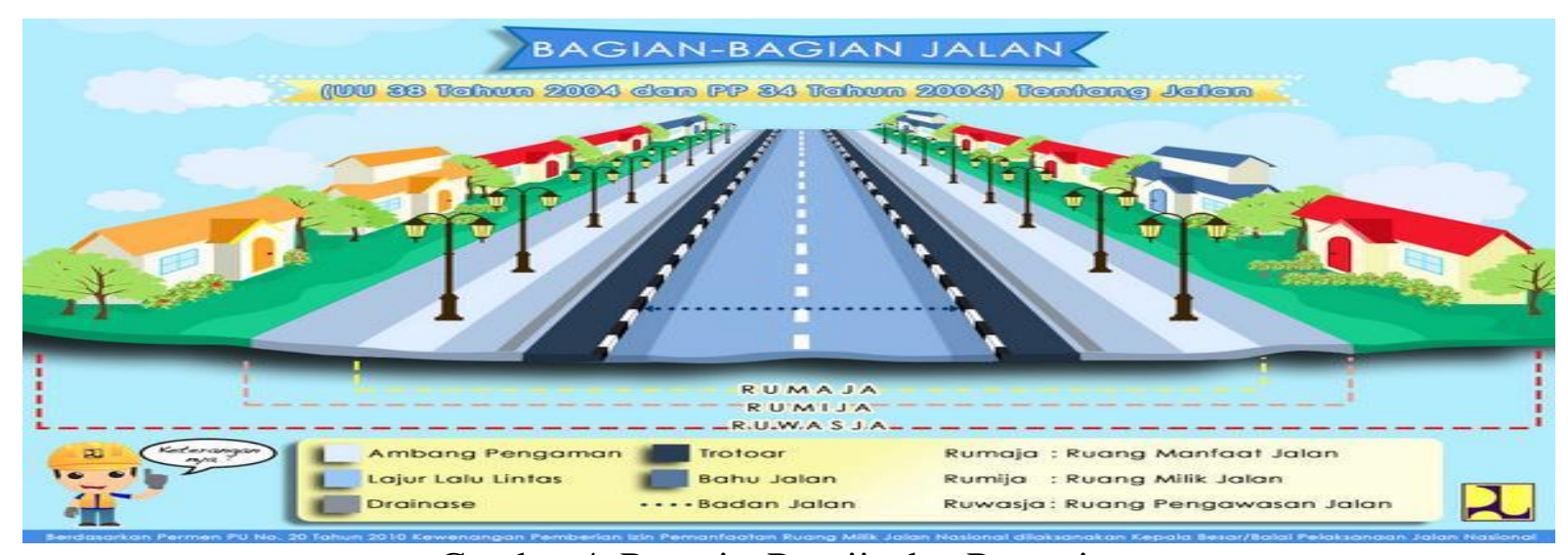

Gambar 4. Rumaja, Rumija dan Ruwasja

Sumber : Kementerian PUPR, 2020

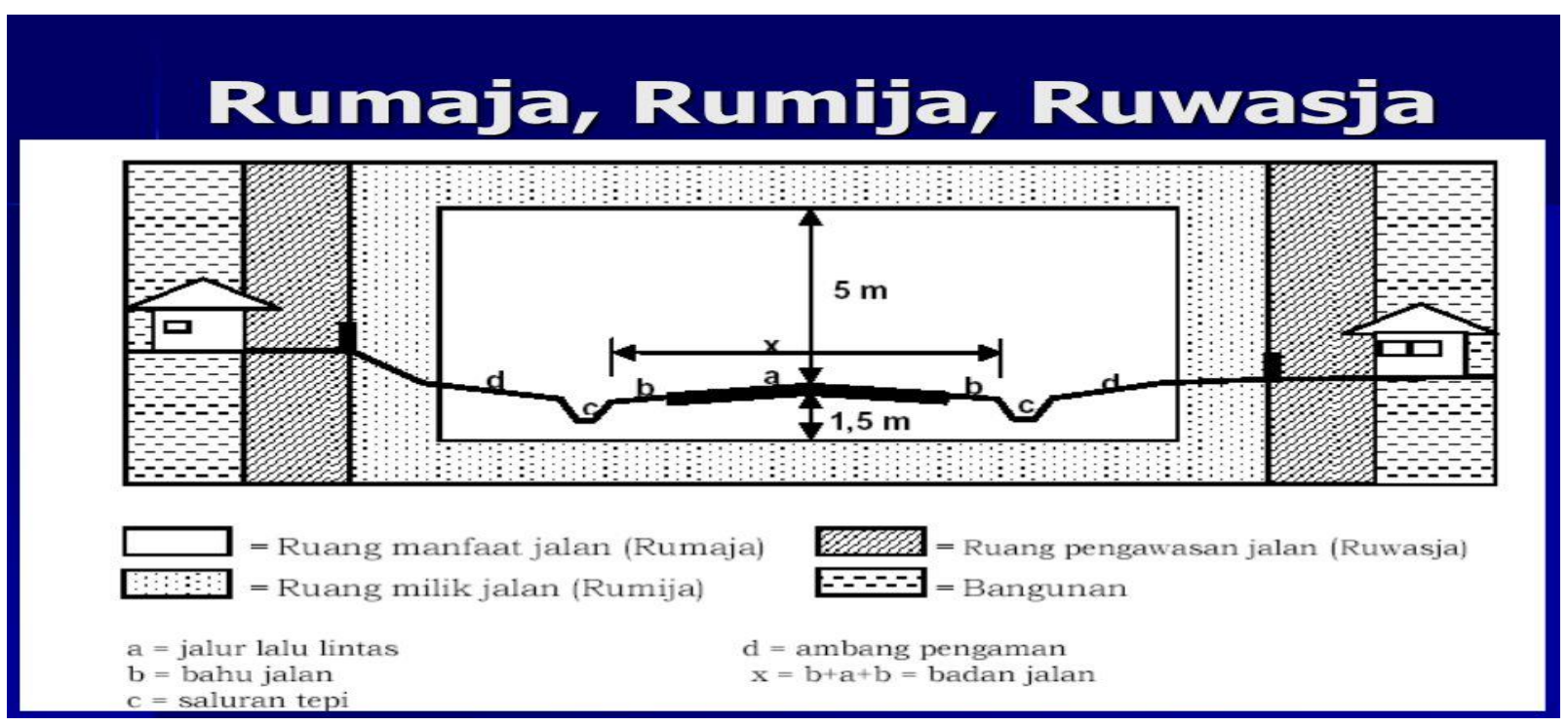

Gambar 5. Tampang Melintang Rumaja, Rumija dan Ruwasja

Sumber : Kementerian PUPR, 2020

Jalan raya adalah jalur-jalur tanah diatas permukaan bumi yang dibuat oleh manusia dengan bentuk ukuran-ukuran dan jenis kontruksinya sehingga dapat digunakan untuk menyalurkan lalu lintas kendaraan maupun pejalan kaki, hewan dan kendaraan yang mengangkut barang dari suatu tempat ke tempat yang lainnya dengan mudah dan cepat untuk perencanaan jalan raya yang baik (Clarkson H.Oglesby, 1999). Untuk perencanaan jalan raya yang baik, bentuk geometriknya harus ditetapkan sedemikian rupa sehingga jalan yang bersangkutan dapat memberikan pelayanan yang optimal kepada lalu lintas sesuai dengan fungsinya, sebab tujuan akhir dari perencanaan geometrik ini adalah menghasilkan infrastruktur yang aman, efisiensi pelayanan arus lalu lintas dan memaksimalkan ratio tingkat penggunaan biaya juga memberikan rasa aman dan nyaman kepada pengguna jalan.

\section{Data Lalu Lintas}

Data lalu lintas merupakan data utama dari suatu perencanaan lalu lintas di samping pengaruhnya yang sangat besar terhadap perencanaan bentuk seperti lebar, alignemen, kelandaian dan sebagainya, juga yang terpenting bahwa data tersebut memerlukan pemahaman yang di perlukan bagi suatu jalan. Menurut (F.D, Hobbs, 1995). Cara pengaturan dan pengendalian lalu lintas telah berkembang sejalan dengan perkembangan angkutan 
beroda serta konsekuensi sosial dan komersial penggunanya. Penggunaan tanah dan rencana distribusi spesialnya merupakan penentu dasar bagi kebutuhan lalu lintas kendaraan. jumlah dan jenis lalu lintas yang terbangkitan oleh suatu guna tanah dapat diukur. Tiap guna tanah, baik sebagai sekolah, pabrik, perumahan atau taman adalah pembangkit lalu lintas. Oleh sebab itu untuk merencanakan suatu jalan dengan keterangan lalu lintas dalam kegiatan ini antara lain sebagai berikut:

1. Klasifikasi jalan

2. Volume lalu lintas

3. Waktu perjalanan

\section{Volume Lalu Lintas}

Sebagai pengukur jumlah dari arus lalu lintas digunakan volume lalu lintas menunjukan jumlah kendaraan yang melintasi satu titik pengamatan dalam satu-satuan waktu (hari, jam, menit) satuan volume lalu lintas yang umum dipergunakan adalah sebagai berikut:

1. Lalu lintas harian rata-rata (LHR)

2. Volume jam perencanaan (VJP)

\section{Komposisi Lalu-Lintas}

Arus atau volume lalu-lintas pada suatu jalan raya diukur berdasarkan jumlah kendaraan yang melewati titik tertentu selama selang waktu tertentu. Dalam beberapa hal, lalu-lintas dinyatakan dengan lalu-lintas harian rata-rata per tahun, yang disebut AADT (Average Annual Daily Traffic) atau Lalu- Lintas Harian Rata-Rata (LHR) bila periode pengamatannya kurang dari satu tahun. Di samping itu, volume lalu-lintas juga dapat diukur dan dinyatakan per jam, seperti volume lalu-lintas yang diamati tiap jam.Beberapa jawatan sekarang memakai selang waktu 5 menit guna membedakan gerakan lalu lintas pada periode puncak yang biasanya terjadi dalam waktu relatif singkat.(Oglesby dan Hicks 1999).

Menurut UU No 22 tahun 2009 lalu-lintas dan angkutan jalan tentang ketentuan umum sebagai berikut:

1. Lalu lintas dan angkutan jalan adalah satu kesatuan sistem yang terdiri atas lalu-lintas, angkutan jalan, jaringan lalu-lintas dan angkutan jalan, prasarana lalu-lintas dan angkutan jalan, kendaraan, pengemudi, pengguna jalan, sertapengelolaannya.

2. Lalu lintas adalah gerak kendaraan dan orang di ruang lalu-lintas jalan.

3. Angkutan adalah perpindahan orang dan barang dari satu tempat ke tempat lain dengan menggunakan kendaraan di ruang lalu-lintas jalan.

4. Jaringan lalu lintas dan angkutan jalan adalah serangkaian simpul dan ruang kegiatan yang saling terhubungkan untuk penyelenggaraan lalu-lintas dan angkutan jalan.

Volume lalu lintas harian rata-rata (VLHR) adalah perkiraan volume lalu lintas harian pada akhir tahun rencana lalu lintas dinyatakan dalam smp/hari. (MKJI 1997).

\section{Kinerja Ruas Jalan}

Kinerja ruas jalan digunakan untuk mengevaluasi permasalan lalu lintas pada suatu jalan. Kinerja jalan digambarkan berdasarkan kondisi kestabilan jalan, waktu tempuh bagi kendaraan untuk melewati segmen jalan tersebut, tingkat kejenuhan lalu lintas pada segmen jalan dan kecepatan bebas setiap kendaraan dalam melalui segmen. Beberapa kinerja ruas jalan diterangkan sebagai berikut : 
Nisbah Volume dan Kapasitas

Tabel 1. Nilai NVK

\begin{tabular}{|c|c|}
\hline NVK & KETERANGAN \\
\hline$<0,8$ & Kondisi stabil \\
$0,8-1,0$ & Kondisi tidak stabil \\
$>1,0$ & Kondisi kritis \\
\hline
\end{tabular}

Sumber: Tamin \& Nahdalina (1998)

Tingkat Pelayanan, pada tabel berikut ini ditunjukkan kategori tingkat pelayanan ruas jalan.

Tabel 2. Indeks Pelayanan Berdasarkan Kecepatan Rata-rata

\begin{tabular}{|c|c|c|c|}
\hline Kelas arteri & $\mathrm{L}$ & $\mathrm{Ll}$ & 111 \\
\hline Kecepatan (km/jam) & $72-56$ & $56-48$ & $56-40$ \\
\hline ITP & \multicolumn{3}{|c|}{ Kecepatan rata- rata (km/jam) } \\
\hline A & $\geq 56$ & $\geq 48$ & $\geq 40$ \\
B & $\geq 45$ & $\geq 38$ & $\geq 31$ \\
C & $\geq 35$ & $\geq 29$ & $\geq 21$ \\
D & $\geq 28$ & $\geq 23$ & $\geq 15$ \\
E & $\geq 21$ & $\geq 16$ & $\geq 11$ \\
F & $<21$ & $<16$ & $<11$ \\
\hline
\end{tabular}

Sumber: Tamin \& Nahdalina (1998)

Tabel 3. Indeks Pelayanan Berdasarkan Kecepatan Arus Bebas Dan Tingkat Kejenuhan Lalu Lintas

\begin{tabular}{|c|c|c|}
\hline Tingkat pelayanan & \% Dari kecepatan bebas & Tingkat kejenuhan \\
\hline A & $\geq 90$ & $\geq 0,35$ \\
B & $\geq 70$ & $\geq 0,54$ \\
C & $\geq 50$ & $\geq 0,77$ \\
D & $\geq 40$ & $\geq 0,93$ \\
E & $\geq 33$ & $\geq 1,0$ \\
F & $<33$ & $<1,0$ \\
\hline
\end{tabular}

Sumber: Tamin \& Nahdalina (1998)

\section{Kapasitas Jalan}

Menurut Marlok E.K (1991) terhadap adanya dua konsep kapasitas dalam analisis ini merupakan jumlah kendaraan yang menggunakan jalan tersebut yaitu:

1. Konsep pertama menyatakan bahwa jumlah kendaraan yang melintas di jalur agar lebih lancar efekif dan maksimal,

2. Konsep yang kedua kapasitas merupakan volume maksimum yang dapat di tempuh waktu atau kelambatan yang masih dapat diterima.

Kapasitas adalah volume kendaraan maksimum yang dapat melewati suatu ruas jalan atau persimpangan dalam kondisi yang umum. Atau kapasitas lebih dikenal sebagai "daya tampung maksimum" suatu ruas jalan atau persimpangan terhadap volume lalu lintas yang melewati dalam satuan waktu tertentu. Satuan kapasitas atau daya tampung suatu ruas jalan dinyatakan 
dengan smp/jam. Sedangkan Manual Kapasitas Jalan Indonesia (MKJI) Tahun 1997 mendefinisikan Kapasitas sebagai arus lalulintas maksimum melalui suatu titik di jalan yang dapat dipertahankan per-satuan waktu pada kondisi yang ideal. Untuk jalan dua lajur dua arah, kapasitas ditentukan untuk arus dua arah (kombinasi dua arah), tetapi untuk jalan dengan banyak lajur, arus dipisahkan per-arah dan kapasitas ditentukan per-lajur. Rumus untuk menghitung kapasitas jalan kota berdasarkan Manual Kapasitas Jalan Indonesia (MKJI) Tahun 1997 adalah :

$\mathrm{C} \quad=$ Kapasitas $(\mathrm{smp} / \mathrm{jam})$

$$
\text { C }=\operatorname{Co} \times \text { Fcw } \times \text { Fesp } \times \text { Fcsf } \times \text { Fes }
$$

Co = Kapasitas dasar (tabel)

$\mathrm{Fcw}=$ Faktor penyesuaian lebar jalan (tabel)

Fcsp = Faktor penyesuaian arah lalu lintas (tabel)

Fcsf = Faktor hambatan samping (tabel)

Fccs = Faktor ukuran kota (tabel)

Manual Kapasitas Jalan Indonesia Tahun 1997 mendefinisikan hal-hal sebagai berikut: Kapasitas dasar (Co) sebagai kapasitas ideal untuk kondisi ideal. Jika kondisi sesungguhnya adalah sama dengan kondisi ideal, maka semua factor penyesuaian bernilai 1,0 dan kapasitas menjadi sama dengan kapasitas dasar (Co).

a. Kondisi ideal untuk jalan dua lajur - dua arah (2/2 UD) didefinisikan sebagai :

- Lebar jalur lalulintas adalah 7 meter,

- Lebar bahu efektif paling sedikit $2 \mathrm{~m}$ pada setiap sisi,

- Tidak ada median,

- Pemisahan arah (split) lalulintas adalah $50: 50$,

- Hambatan samping rendah,

- Ukuran kota 1,0 - 3,0 juta,

- Tipe alinemen datar.

b. Kondisi ideal untuk jalan empat lajur - dua arah terbagi (4/2D) dan tak terbagi

(4/2 UD) didefinisikan sebagai berikut :

- Lebar lajur 3,5 m (lebar jalan lalu lintas total 14,0 m),

- Kerb (tanpa bahu jalan),

- Jarak antara kerb ke penghalang terdekat pada trotoar $\geq 2 \mathrm{~m}$,

- Median, pemisahan arah lalulintas (split) adalah $50: 50$,

- Hambatan samping rendah,

- Ukuran kota 1,0 - 3,0 juta,

- Tipe alinemen datar.

c. Kondisi ideal untuk jalan enam lajur-dua arah terbagi (6/2 D) didefinisikan sebagai berikut :

- Lebar lajur 3,5 m (lebar jalan lalulintas total 21,0 m),

- Kerb (tanpa bahu jalan),

- Jarak antara kerb ke penghalang terdekat pada trotoar $\geq 2 \mathrm{~m}$,

- Median, pemisahan arah lalulintas (split) adalah $50: 50$,

- Hambatan samping rendah,

- Ukuran kota 1,0 - 3,0 juta,

- Tipe alinemen datar.

d. Kondisi ideal untuk jalan satu arah didefinisikan sebagai berikut :

- Lebar jalan adalah 7,0 m,

- Lebar bahu jalan efektif minimal 2 m pada setiap sisi, dan tidak ada median, 
- Hambatan samping rendah,

- Ukuran kota 1,0 - 3,0 juta,

- Tipe alinemen datar.

Kapasitas dasar jalan tergantung pada tipe jalan, jumlah lajur dan apakah jalan dipisah dengan pemisah fisik atau tidak. Adapun nilai variable-variabel yang termasuk dalam kapasitas, antara lain:

\section{Faktor kapasitas dasar $(\mathrm{Co})$}

Tabel 4. Kapasitas Dasar Jalan Antar Kota (Co)

\begin{tabular}{|l|c|l|}
\hline \multicolumn{1}{|c|}{$\begin{array}{c}\text { Tipe jalan/ } \\
\text { Tipe alinyemen }\end{array}$} & $\begin{array}{c}\text { Kapasitas dasar } \\
(\mathrm{smp} / \mathrm{jam})\end{array}$ & Keterangan \\
\hline 4 Lajur terbagi Datar Berbukit & 1900 & \\
Pegunungan & 1850 & Per lajur \\
\hline 4 Lajur tak terbagi Datar & 1800 & \\
Berbukit & 1700 & Per lajur \\
Pegunungan & 1650 & \multirow{2}{*}{ Total lajur } \\
\hline 2 Lajur tak terbagi Datar & 1600 & \\
Berbukit & 3100 & 3000 \\
Pegunungan & 2900 & \\
\hline
\end{tabular}

atau menggunakan Kapasitas Dasar (SMP/JAM) sebagai berikut :

Tabel 5. Kapasitas Dasar Jalan (Co)

\begin{tabular}{|l|c|}
\hline \multicolumn{1}{|c|}{ Tipe Jalan } & $\begin{array}{c}\text { Kapasitas Dasar } \\
\text { (smp/jam) }\end{array}$ \\
\hline Jalan 4 lajur keterpembatas median atau jalan satu arah & 1,650 per lajur \\
\hline Jalan 4 lajur tanpa pembatas median & 1,500 per lajur \\
\hline Jalan 2 jalur tanpa pembatas median & 2,900 total dua arah \\
\hline
\end{tabular}

Sumber : Indonesian Highwoy Copocity Manual (IHCM 1997)

\section{Faktor penyesuaian kapasitas akibat pemisah arah (Fcsp)}

Tabel 6. Penyesuaian kapasitas akibat pemisah arah (Fcsp)

\begin{tabular}{|c|c|c|c|c|c|}
\hline Pemisah arah SP \% - \% & $50-50$ & $55-45$ & $60-40$ & $65-35$ & $70-30$ \\
\hline Dua - lajur (2/2 UD) & 1,00 & 0,97 & 0,94 & 0,91 & 0,88 \\
\hline Empat - lajur (4/2 UD) & 1,00 & 0,975 & 0,95 & 0.925 & 0,90 \\
\hline
\end{tabular}

Sumber: MKJI 1997 
JURNAL KACAPURI

JURNAL KEILMUAN TEKNIK SIPIL

Volume 3 Nomor 1 Edisi Juni 2020

Faktor penyesuaian kapasitas akibat lebar jalur lalu lintas (Fcw)

Tabel 7.Penyesuaian Kapasitas akibat Pengaruh Lebar Jalur Lalu Lintas (Fcw)

\begin{tabular}{|c|c|c|}
\hline Tipe jalan & Lebar efektif jalan & Fcw \\
\hline \multirow{3}{*}{ Empat - lajur terbagi Enam - } & Per lajur & 0,91 \\
lajur terbagi & 3,00 & 0,96 \\
& 3,25 & 1,00 \\
& 3,50 & 1,03 \\
\hline \multirow{3}{*}{ Empat - lajur tak terbagi } & 3,75 & \\
& Per lajur & 0,91 \\
& 3,00 & 0,96 \\
& 3,25 & 1,00 \\
& 3,50 & 1,03 \\
\hline & 3,75 & 0,69 \\
Dua - lajur tak terbagi & Total kedua arah & 0,91 \\
& 5 & 1,00 \\
& 7 & 1,08 \\
& 8 & 1,15 \\
& 9 & 1,21 \\
& 10 & 1,27 \\
\hline
\end{tabular}

Sumber : MKJI 1997

Faktor hambatan samping (Fesf)

Tabel 8. Faktor Hambatan Samping (Fcsf)

\begin{tabular}{|c|c|c|c|c|c|}
\hline \multirow[t]{3}{*}{ Tipe jalan } & \multirow{3}{*}{$\begin{array}{l}\text { Kelas } \\
\text { hambatan } \\
\text { samping }\end{array}$} & \multicolumn{4}{|c|}{$\begin{array}{l}\text { Faktor penyesuaian untuk hambatan samping dan lebar bahu } \\
\qquad \text { FCSF }\end{array}$} \\
\hline & & \multicolumn{4}{|c|}{ Lebar bahu efektif $w_{S}$} \\
\hline & & $\leq 0,5$ & 1,0 & 1,5 & $\geq 2,0$ \\
\hline $4 / 2 \mathrm{D}$ & $\begin{array}{l}\text { VL } \\
\text { L } \\
\text { M } \\
\text { H } \\
\text { VH }\end{array}$ & $\begin{array}{l}0,96 \\
0,94 \\
0,92 \\
0,88 \\
0,84\end{array}$ & $\begin{array}{l}0,98 \\
0,97 \\
0,95 \\
0,92 \\
0,88\end{array}$ & $\begin{array}{l}1,01 \\
1,00 \\
0,98 \\
0,95 \\
0,92\end{array}$ & $\begin{array}{l}1,03 \\
1,02 \\
1,00 \\
0,98 \\
0,96\end{array}$ \\
\hline $4 / 2$ UD & $\begin{array}{l}\text { VL } \\
\text { L } \\
\text { M } \\
\text { H } \\
\text { VH }\end{array}$ & $\begin{array}{l}0,96 \\
0,94 \\
0,92 \\
0,87 \\
0,80\end{array}$ & $\begin{array}{l}0,99 \\
0,97 \\
0,95 \\
0,91 \\
0,86\end{array}$ & $\begin{array}{l}1,01 \\
1,00 \\
0,98 \\
0,94 \\
0,90\end{array}$ & $\begin{array}{l}1,03 \\
1,02 \\
1,00 \\
0,98 \\
0,95\end{array}$ \\
\hline $\begin{array}{l}2 / 2 \text { UD } \\
\text { atau } \\
\text { Jalan satu- } \\
\text { arah }\end{array}$ & $\begin{array}{l}\text { VL } \\
\text { L } \\
\text { M } \\
\text { H } \\
\text { VH }\end{array}$ & $\begin{array}{l}0,94 \\
0,92 \\
0,89 \\
0,82 \\
0,73\end{array}$ & $\begin{array}{l}0,96 \\
0,94 \\
0,92 \\
0,86 \\
0,79\end{array}$ & $\begin{array}{l}0,99 \\
0,97 \\
0,95 \\
0,90 \\
0,85\end{array}$ & $\begin{array}{l}1,01 \\
1,00 \\
0,98 \\
0,95 \\
0,91\end{array}$ \\
\hline
\end{tabular}

Sumber : MKJI 1997 


\section{Faktor ukuran kota (Fces)}

Tabel 9. Faktor Ukuran Kota (Fccs)

\begin{tabular}{|c|c|}
\hline $\begin{array}{c}\text { Ukuran Kota } \\
\text { (Juta penduduk) }\end{array}$ & $\begin{array}{c}\text { Faktor Penyesuaian Untuk } \\
\text { Ukuran Kota (FCcs) }\end{array}$ \\
\hline \hline 0.1 & 0.86 \\
$0.1-0.5$ & 0.90 \\
$0.5-1.0$ & 0.94 \\
$1.0-3.0$ & 1.00 \\
$>3.0$ & 1.04 \\
\hline
\end{tabular}

Sumber: MKJI, 1997

\section{Geometrik Jalan}

\section{Lebar jalur lalu lintas}

Pertambahan jalur lalu lintas akan menyebabkan peningkatan lalu lintas sehingga kapasitas jalanpun meningkat. Jalur lalu lintas (traveled way = carriage way) adalah bagian perkerasaan jalan yang di peruntuhkan bagi lalu lintas kendaraan. Jalur lalu lintas terdiri dari beberapa jalur (line) kendaraan. Lajur kendaraan yaitu bagian jalur lalu lintas yang khusus untuk dilewati oleh satu rangkaian kendaraan beroda empat atau lebih dalam satu arah. Menurut Silvia Sukirman (1994) lebar jalur lalu lintas adalah bagian yang paling menentukan lebar melintang jalan secara keseluruhan. Lebar jalur lalu lintas merupakan lebar kendaraan di tambah dengan ruang bebas antara kendaraan yang besarnya sangat ditentukan oleh keamanan dan kenyamanan yang diharapkan. Jalan yang di pergunakan untuk lalu lintas kecepatan tinggi, membutuhkan ruang bebas untuk menyalip dan bergerakan yang lebih besar di bandingkan dengan jalan untuk kecepatan rendah.

\section{Lebar Bahu Jalan}

Bahu jalan adalah jalur yang terletak berdampingan dengan jalur lalu lintas yang berfungsi sebagai berikut :

a. Ruang untuk berhenti kendaraan yang mogok atau berhenti sejenak. Ruang untuk tempat menghindarkan diri saat darurat sehingga untuk mencegah terjadi kecelakaan.

b. Memberi kelegaan pada pengemudi, dengan meningkatkan kapasitas jalan yang bersangkutan.

c. Memberi sokongan pada konstruksi perkerasaan dari arah samping.

d. Ruang pembantu pada waktu pekerjaan perbaikan jalan atau penempatan alat-alat, dan penimbunan bahan material.

\section{Densitas (Ds)}

Densitas atau derajat kejenuhan atau indeks dari suatu ukuran yang digunakan untuk mengetahui kualitas suatu ruas jalan tertentu dalam melayani arus lalu lintas yang melewatinya.

Ds berupa angka indeks.

$$
\begin{array}{ll}
\mathrm{Ds} & =\mathrm{V} / \mathrm{C} \\
\mathrm{V} & =\text { Volume kendaraan }(\mathrm{smp}) \\
\mathrm{C} & =\text { Kapasitas Jalan }(\mathrm{smp} / \mathrm{jam})
\end{array}
$$

\section{Level of Service (LOS)}

Tingkat pelayanan atau "Level of Service" adalah tingkat pelayanan dari suatu jalan yang menggambarkan kualitas suatu jalan dan merupakan batas kondisi pengoperasian. Tingkat 
pelayanan suatu jalan merupakan ukuran kualitatif yang digunakan United States Highway Capacity Manual (USHCM 1985) yang menggambarkan kondisi operasional lalu lintas dan penilaian oleh pemakai jalan. Ukuran tingkat pelayanan adalah tingkat pelayanan suatu jalan menunjukan kualitas jalan diukur dari beberapa faktor, yaitu: kecepatan dan waktu tempuh; kerapatan (density); tundaan (delay); arus lalu lintas dan arus jenuh (saturation flow) dan derajat kejenuhan (degree of saturation). Klasifikasi tingkat pelayanan. Tingkat pelayanan tergantung arus. Tingkat pelayanan A (arus bebas); tingkat pelayanan B (arus stabil, untuk merancang jalan antar kota); tingkat pelayanan $\mathrm{C}$ (arus stabil, untuk merancang jalan perkotaan); tingkat pelayanan D (arus mulai tidak stabil); tingkat pelayanan E (Arus tidak stabil) dan tingkat pelayanan F (arus terpaksa).

Tabel 10. Tingkat Pelayanan Tergantung Fasilitas

\begin{tabular}{|c|c|l|}
\hline V/C Rasio & Tingkat Pelayanan Jalan & \multicolumn{1}{|c|}{ Keterangan } \\
\hline$<0.60$ & $\mathrm{~A}$ & Arus lancar, volume rendah, kecepatan tinggi \\
\hline 0.60 & $\mathrm{~B}$ & Arus stabil, kecepatan terbatas, volume sesui kecepatan \\
0.70 & & jalan kota \\
\hline 0.70 & $\mathrm{C}$ & Arus stabil, kecepatan dipengaruhi arus lalu lintas, \\
0.80 & & volume sesui untuk jalan kota \\
\hline 0.80 & $\mathrm{D}$ & Mendekati arus tidak stabil, kecepatan rendah \\
0.90 & $\mathrm{E}$ & Mendekati arus tidak stabil, kecepatan rendah, volume \\
\hline 0.90 & & padat atau mendekati kapasitas \\
1.00 & $\mathrm{~F}$ & Arus yang terhambat, kecepatan rendah, volume di atas \\
\hline 1.00 & & kapasitas, banyak terhenti \\
\hline
\end{tabular}

Sumber: Morlok E.K, 1991.

Manual Kapasitas Jalan Indonesia (MKJI, 1997) mendefinisikan Tingkat Pelayanan suatu ruas jalan sebagai ukuran kualitatif yang mencerminkan persepsi pengemudi tentang kualitas mengendarai kendaraan. Tingkat Pelayanan Jalan atau Level of Service (LOS) adalah suatu metode yang mungkin untuk memberikan batasan-batasan ukuran untuk dapat menjawab pertanyaan "Apakah kondisi suatu ruas jalan yang ada saat ini masih memenuhi syarat untuk dilalui oleh volume maksimum lalu lintas atau menunjukan kinerja dari suatu ruas jalan”.

Tingkat pelayanan A :

1. Arus bebas dengan volume lalu lintas rendah dan kecepatan tinggi;

2. Kepadatan lalu lintas sangat rendah dengan kecepatan yang dapat dikendalikan oleh pengemudi berdasarkan batasan kecepatan maksimum/minimum dan kondisi fisik jalan;

3. Pengemudi dapat mempertahankan kecepatan yang diinginkannya tanpa atau dengan sedikit tundaan.
Tingkat pelayanan $\mathrm{B}$ :

1. Arus stabil dengan volume lalu lintas sedang dan kecepatan mulai dibatasi oleh kondisi lalu lintas;

2. Kepadatan lalu lintas rendah hambatan internal lalu lintas belum memengaruhi kecepatan;

3. Pengemudi masih punya cukup kebebasan untuk memilih kecepatannya dan lajur jalan yang digunakan 


\begin{tabular}{|c|c|}
\hline $\begin{array}{l}\text { Tingkat pelayanan } \mathrm{C} \text { : } \\
\text { 1. Arus stabil tetapi kecepatan dan } \\
\text { pergerakan kendaraan dikendalikan oleh } \\
\text { volume lalu lintas yang lebih tinggi; } \\
\text { 2. Kepadatan lalu lintas sedang karena } \\
\text { hambatan internal lalu lintas meningkat; } \\
\text { 3. Pengemudi memiliki keterbatasan untuk } \\
\text { memilih kecepatan, pindah lajur atau } \\
\text { mendahului. }\end{array}$ & $\begin{array}{l}\text { Tingkat pelayanan D : } \\
\text { 1. Arus mendekati tidak stabil dengan } \\
\text { volume lalu lintas tinggi dan kecepatan } \\
\text { masih ditolerir namun sangat } \\
\text { terpengaruh oleh perubahan kondisi } \\
\text { arus; } \\
\text { 2. Kepadatan lalu lintas sedang namun } \\
\text { fluktuasi volume lalu lintas dan } \\
\text { hambatan temporer dapat menyebabkan } \\
\text { penurunan kecepatan yang besar; } \\
\text { 3. Pengemudi memiliki kebebasan yang } \\
\text { sangat terbatas dalam menjalankan } \\
\text { kendaraan, kenyamanan rendah, tetapi } \\
\text { kondisi ini masih dapat ditolerir untuk } \\
\text { waktu yang singkat }\end{array}$ \\
\hline $\begin{array}{l}\text { Tingkat pelayanan E: } \\
\text { 1. Arus lebih rendah daripada tingkat } \\
\text { pelayanan D dengan volume lalu lintas } \\
\text { mendekati kapasitas jalan dan kecepatan } \\
\text { sangat rendah; } \\
\text { 2. Kepadatan lalu lintas tinggi karena } \\
\text { hambatan internal lalu lintas tinggi; } \\
\text { 3. pengemudi mulai merasakan kemacetan- } \\
\text { kemacetan durasi pendek }\end{array}$ & $\begin{array}{l}\text { Tingkat pelayanan } \mathrm{F} \text { : } \\
\text { 1. Arus tertahan dan terjadi antrian } \\
\text { kendaraan yang panjang; } \\
\text { 2. Kepadatan lalu lintas sangat tinggi dan } \\
\text { volume sama dengan kapasitas jalan } \\
\text { serta terjadi kemacetan untuk durasi } \\
\text { yang cukup lama; } \\
\text { 3. Dalam keadaan antrian, kecepatan } \\
\text { maupun arus turun sampai } 0 .\end{array}$ \\
\hline
\end{tabular}

\section{METODE PENELITIAN}

Metode yang digunakan dalam penelitian ini adalah metode deskriptif yaitu analisis kapasitas dan tingkat pelayanan ruas jalan menggunakan MKJI 1997. Yang inputan dari data primer yaitu Traffic Counting (TC) lalu lintas di ruas Jalan Adhyaksa sehingga dapat disimpulkan bahwa metode deskriptif adalah sebuah cara atau teknik yang dilakukan untuk memaparkan suatu permasalahan sehingga dapat dengan jelas dianalisis dan ditarik kesimpulan. Ditinjau dari jenis data dan pendekatan penelitian yang digunakan dalam penelitian ini adalah pendekatan kuantitatif. Adapun yang dimaksud dengan penelitian kuantitatif yaitu penelitian dengan memperoleh data yang berbentuk angka atau data kualitatif yang diangkakan, dan dengan cara deskripstif data yang diperoleh dari sampel popilasi penelitian dianalisis sesuai dengan metode statistik yang digunakan kemudian diinterprestasikan (Sugiyono, 2003:14). Adapun jenis pendekatan penelitian ini adalah deskriptif. Penelitian deskriptif yaitu penelitian yang berusaha untuk menuturkan pemecahan masalah yang ada sekarang berdasarkan data-data. Jenis penelitian deskripif kuantitatif yang digunakan pada penelitian ini dimaksud untuk memeperolah informasi mengenai kinerja ruas jalan Adhyaksa selama satu minggu. 
JURNAL KACAPURI

JURNAL KEILMUAN TEKNIK SIPIL

Volume 3 Nomor 1 Edisi Juni 2020

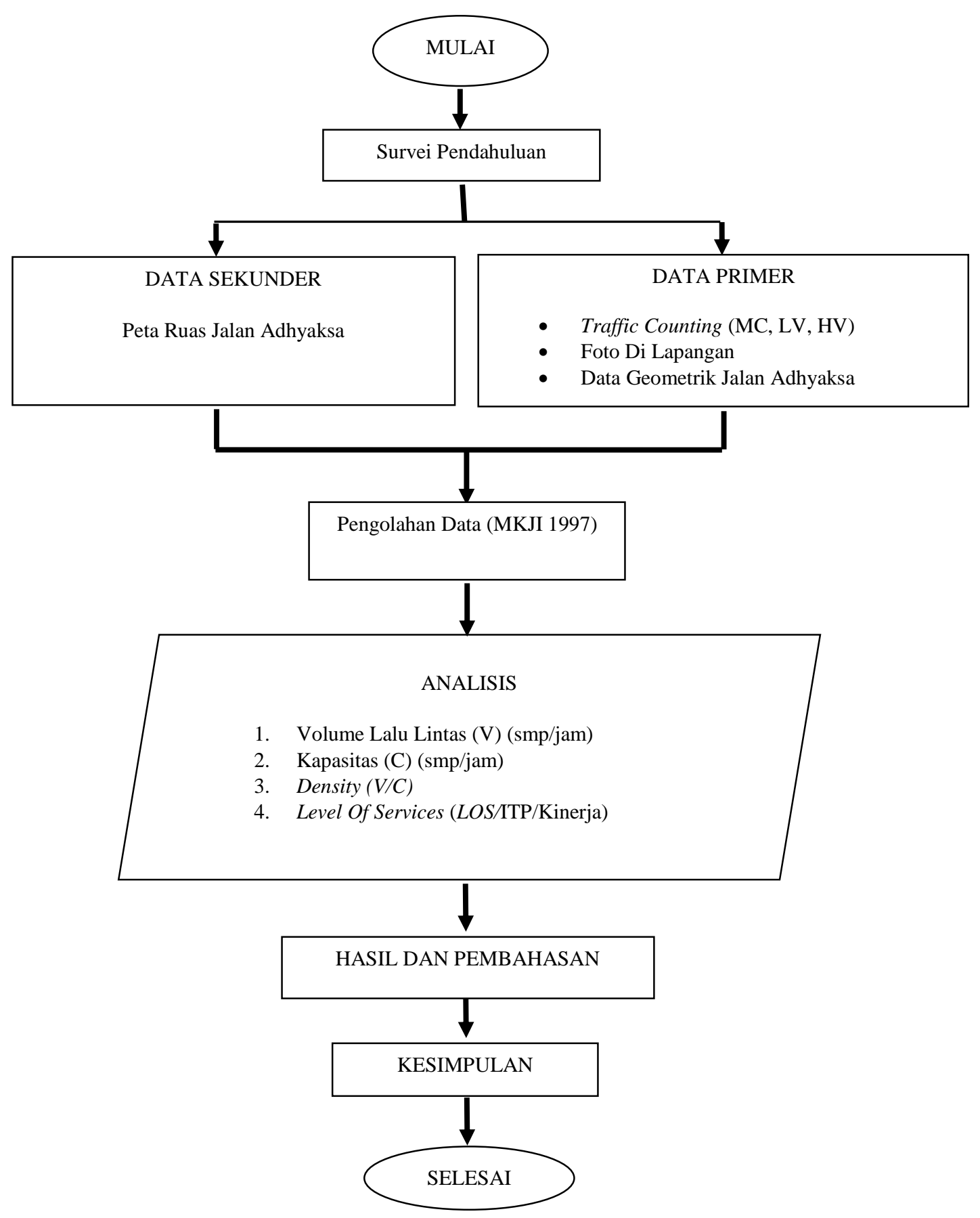

Gambar 6. Diagram Alir Penelitian

Sumber : Analisis, 2020

\section{HASIL DAN PEMBAHASAN}

Berdasarkan hasil dari pengolahan data perhitungan volume, kapasitas, densitas, maka dapat di tentukan nilai Level of service (LOS) pada Jalan Adhyaksa menurut MKJI 1997. 
JURNAL KACAPURI

\section{Hasil Perhitungan di Pos T1}

Tabel 11. Perhitungan Kapasitas Pos T1

\begin{tabular}{|c|c|c|c|c|c|}
\hline Co & FCw & FCsp & FCsf & FCcs & C \\
\hline 2/1D & Lebar Lajur (6.4 m) & Split (50:50) & $\begin{array}{c}\text { Lebar Kereb } \\
(1.6 \mathrm{~m})\end{array}$ & $\begin{array}{c}\text { Penduduk } \\
(<0.1)\end{array}$ & Kapasitas Jalan \\
\hline 2900 & 0,87 & 1 & 0,85 & 0,86 & 1844 \\
\hline
\end{tabular}

Sumber : Analisis, 2020

Tabel 12. Perhitungan Volume Pos T1 (SMP/Jam)

\begin{tabular}{|c|c|c|c|c|r|r|r|}
\hline Waktu & Jumat & Sabtu & Minggu & Senin & Selasa & Rabu & Kamis \\
\hline $08.00-09.00$ & 1877 & 2122 & 1087 & 2257 & 1957 & 2009 & 2245 \\
\hline $09.00-10.00$ & 1643 & 1908 & 1115 & 1928 & 2096 & 2084 & 2508 \\
\hline $10.00-11.00$ & 1842 & 1493 & 1583 & 1681 & 1930 & 2422 & 2181 \\
\hline $11.00-12.00$ & 1846 & 2371 & 1759 & 2465 & 2172 & 2199 & 2272 \\
\hline $12.00-13.00$ & 1332 & 1590 & 1439 & 1486 & 1975 & 1581 & 2632 \\
\hline $13.00-14.00$ & 1600 & 1620 & 1378 & 1537 & 2230 & 1703 & 1616 \\
\hline $14.00-15.00$ & 1693 & 1701 & 1642 & 1831 & 2206 & 2604 & 1501 \\
\hline $15.00-16.00$ & 1428 & 1641 & 1610 & 1949 & 1947 & 2077 & 1619 \\
\hline $16.00-17.00$ & 1469 & 1749 & 1625 & 1699 & 2041 & 1683 & 1917 \\
\hline
\end{tabular}

Sumber : Analisis, 2020

\section{Volume Pos T1 (SMP/jam)}

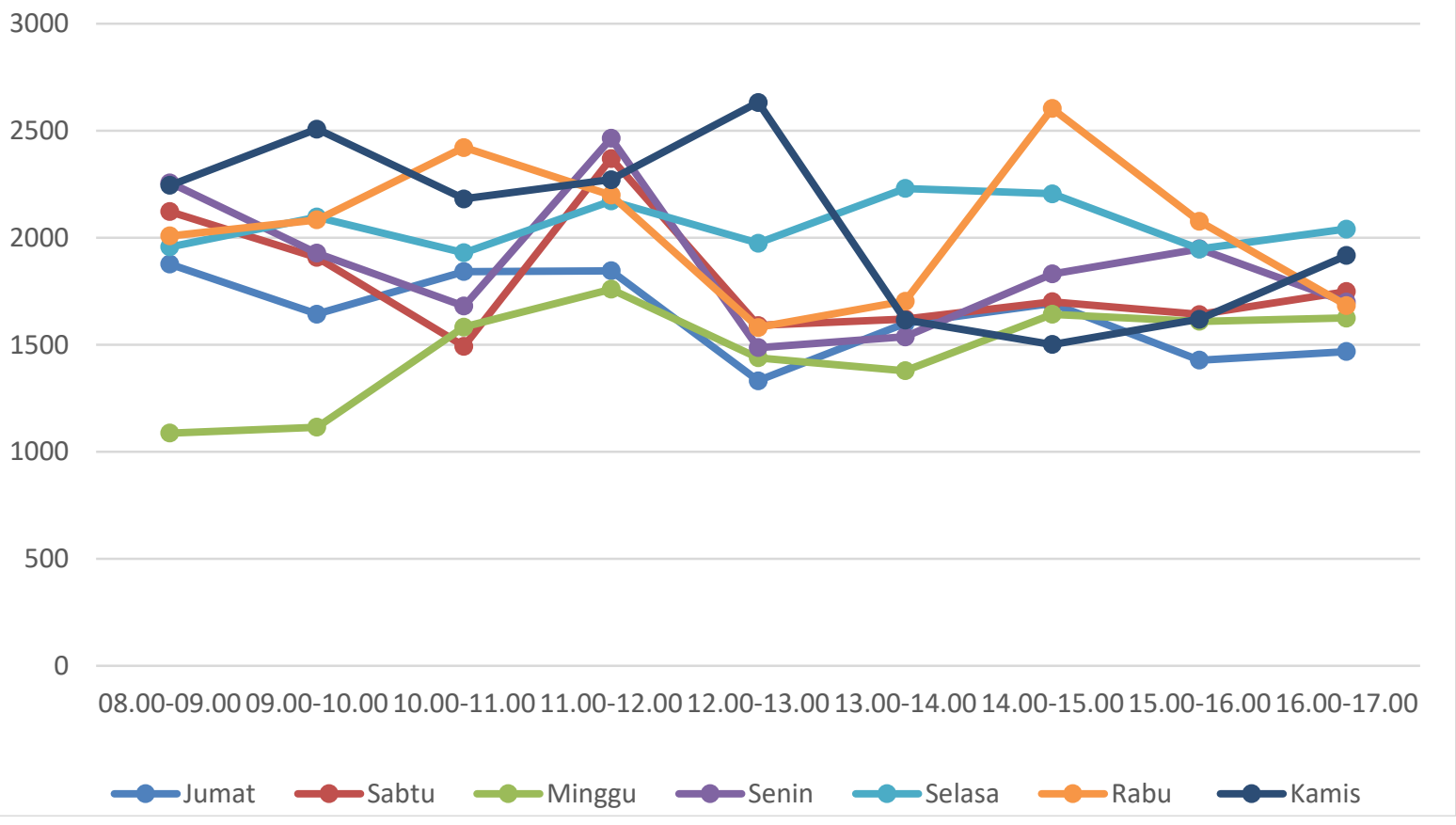

Gambar 7. Grafik Volume Pos T1 (SMP/Jam)

Sumber : Analisis, 2020 
JURNAL KACAPURI

JURNAL KEILMUAN TEKNIK SIPIL

Volume 3 Nomor 1 Edisi Juni 2020

Tabel 13. Perhitungan Densitas Pos T1 (V/C)

\begin{tabular}{|c|r|r|r|r|r|r|r|}
\hline Waktu & \multicolumn{1}{|c|}{ Jumat } & \multicolumn{1}{c|}{ Sabtu } & Minggu & \multicolumn{1}{c|}{ Senin } & Selasa & Rabu & Kamis \\
\hline $08.00-09.00$ & 1,02 & 1,15 & 0,59 & 1,22 & 1,06 & 1,09 & 1,22 \\
\hline $09.00-10.00$ & 0,89 & 1,03 & 0,60 & 1,05 & 1,14 & 1,13 & 1,36 \\
\hline $10.00-11.00$ & 1,00 & 0,81 & 0,86 & 0,91 & 1,05 & 1,31 & 1,18 \\
\hline $11.00-12.00$ & 1,00 & 1,29 & 0,95 & 1,34 & 1,18 & 1,19 & 1,23 \\
\hline $12.00-13.00$ & 0,72 & 0,86 & 0,78 & 0,81 & 1,07 & 0,86 & 1,43 \\
\hline $13.00-14.00$ & 0,87 & 0,88 & 0,75 & 0,83 & 1,21 & 0,92 & 0,88 \\
\hline $14.00-15.00$ & 0,92 & 0,92 & 0,89 & 0,99 & 1,20 & 1,41 & 0,81 \\
\hline $15.00-16.00$ & 0,77 & 0,89 & 0,87 & 1,06 & 1,06 & 1,13 & 0,88 \\
\hline $16.00-17.00$ & 0,80 & 0,95 & 0,88 & 0,92 & 1,11 & 0,91 & 1,04 \\
\hline
\end{tabular}

Sumber: Analisis, 2020

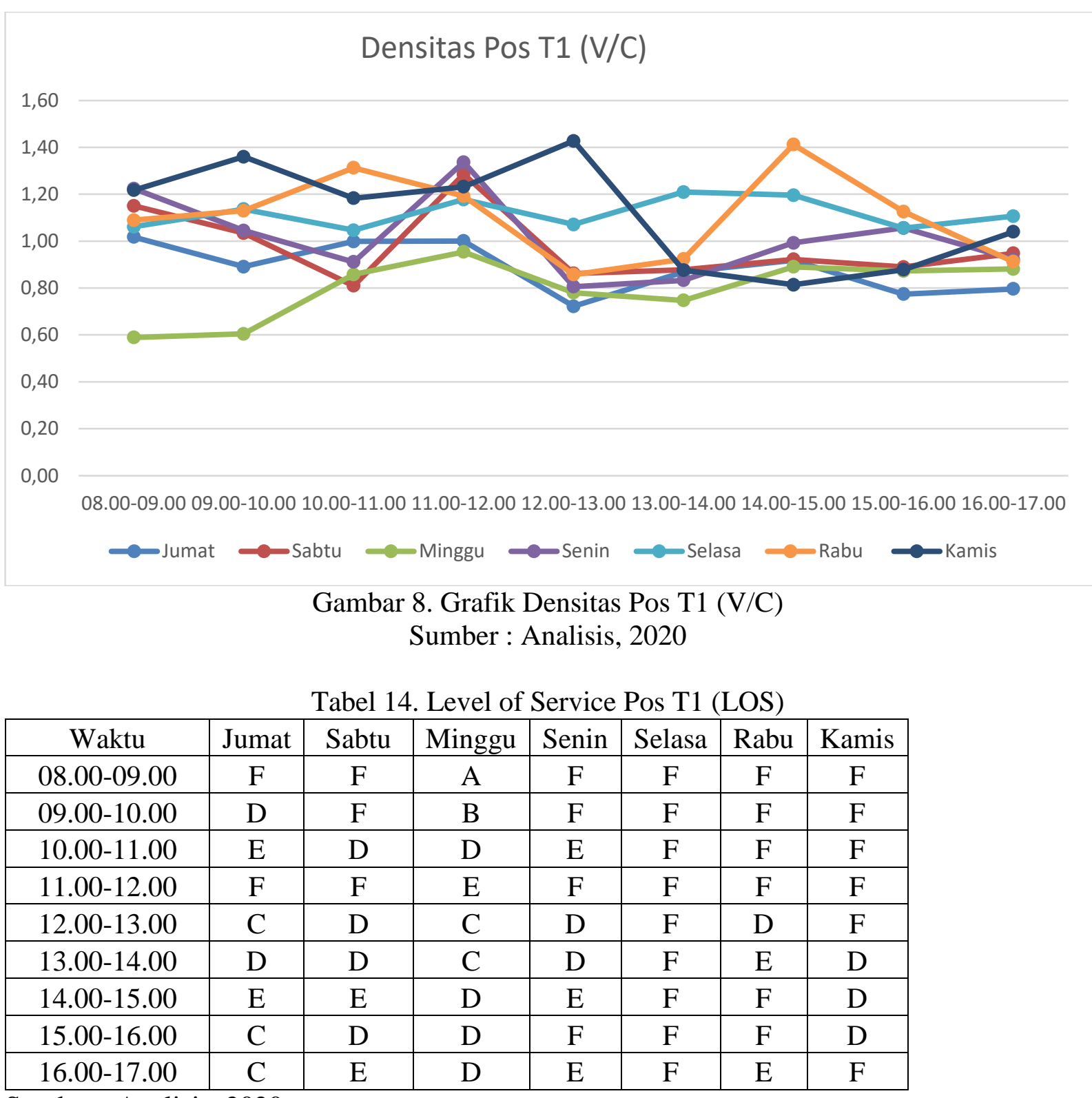

Sumber : Analisis, 2020 
JURNAL KACAPURI

\section{Hasil Perhitungan di Pos T2}

Tabel 15. Perhitungan Kapasitas Pos T2

\begin{tabular}{|c|c|c|c|c|c|}
\hline Co & FCw & FCsp & FCsf & FCcs & C \\
\hline $2 / 1 \mathrm{D}$ & Lebar Lajur (9 m) & Split (50:50) & $\begin{array}{c}\text { Lebar Kereb } \\
(3 \mathrm{~m})\end{array}$ & $\begin{array}{c}\text { Penduduk }( \\
<0.1)\end{array}$ & Kapasitas Jalan \\
\hline 2900 & 1,25 & 1 & 0,91 & 0,86 & 2837 \\
\hline
\end{tabular}

Sumber : Analisis, 2020

Tabel 16. Perhitungan Volume Pos T1 (SMP/Jam)

\begin{tabular}{|c|c|c|c|c|c|c|c|}
\hline Waktu & Jumat & Sabtu & Minggu & Senin & Selasa & Rabu & Kamis \\
\hline $08.00-09.00$ & 2563 & 1895 & 1448 & 2168 & 3127 & 2673 & 2551 \\
\hline $09.00-10.00$ & 2278 & 1862 & 1211 & 2576 & 2735 & 2325 & 2381 \\
\hline $10.00-11.00$ & 1916 & 2043 & 2222 & 2619 & 2742 & 1941 & 2714 \\
\hline $11.00-12.00$ & 2190 & 2222 & 2286 & 1684 & 3117 & 2427 & 2777 \\
\hline $12.00-13.00$ & 1691 & 2350 & 1612 & 2434 & 2330 & 2552 & 3196 \\
\hline $13.00-14.00$ & 1818 & 2383 & 1775 & 2313 & 2771 & 2231 & 1821 \\
\hline $14.00-15.00$ & 2107 & 2489 & 1791 & 1828 & 2411 & 2394 & 1470 \\
\hline $15.00-16.00$ & 1742 & 2227 & 1949 & 1282 & 2495 & 1647 & 2048 \\
\hline $16.00-17.00$ & 1780 & 2028 & 2008 & 1621 & 2481 & 1642 & 2241 \\
\hline
\end{tabular}

Sumber : Analisis, 2020

\section{Volume Pos T2 (SMP/Jam)}

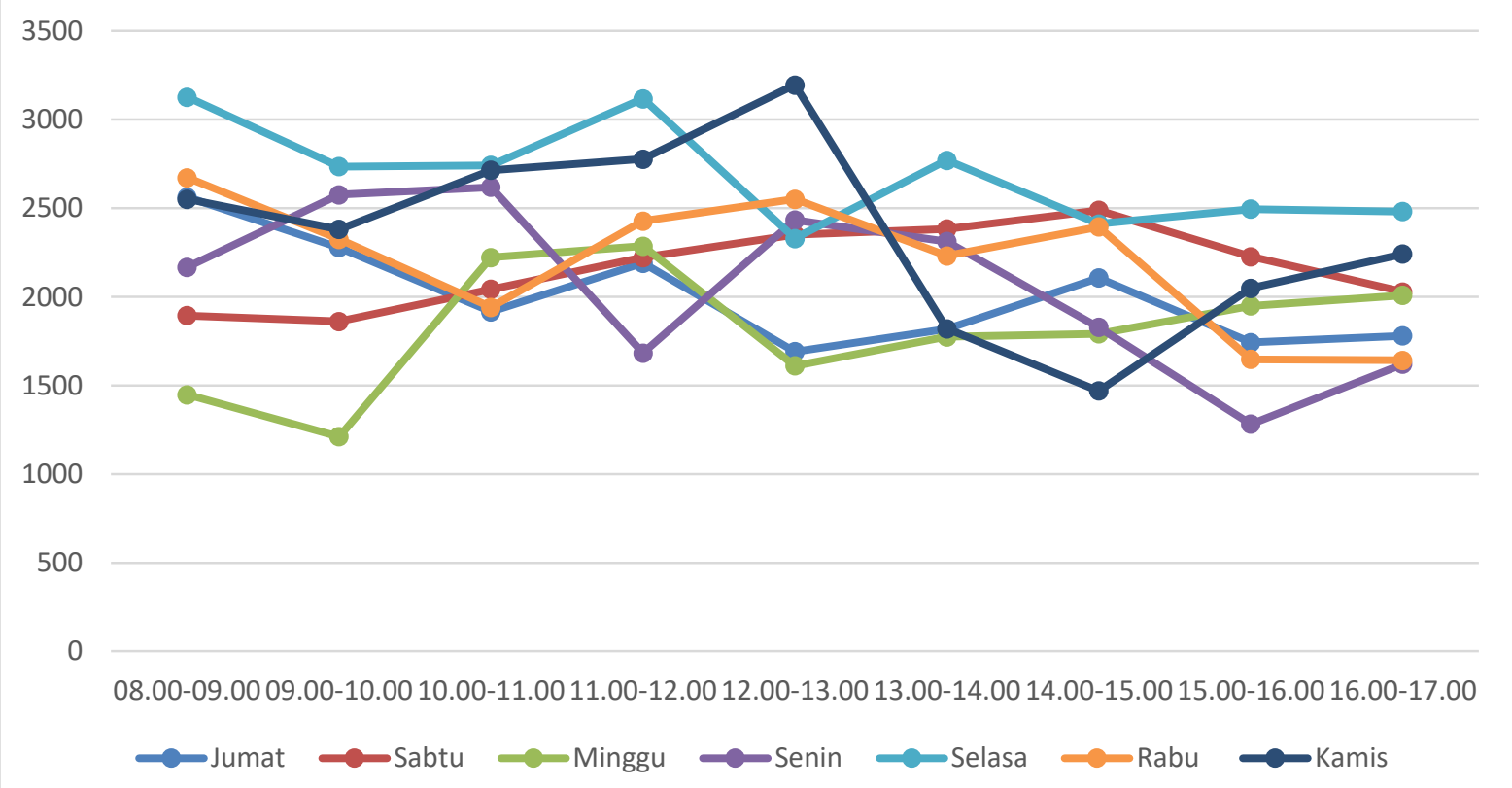

Gambar 9. Grafik Volume Pos T2 (SMP/Jam)

Sumber : Analisis, 2020 
JURNAL KACAPURI

JURNAL KEILMUAN TEKNIK SIPIL

Volume 3 Nomor 1 Edisi Juni 2020

Tabel 17. Perhitungan Densitas Pos T2 (V/C)

\begin{tabular}{|c|c|c|c|c|c|c|c|}
\hline Waktu & Jumat & Sabtu & Minggu & Senin & Selasa & Rabu & Kamis \\
\hline $08.00-09.00$ & 0,90 & 0,67 & 0,51 & 0,76 & 1,10 & 0,94 & 0,90 \\
\hline $09.00-10.00$ & 0,80 & 0,66 & 0,43 & 0,91 & 0,96 & 0,82 & 0,84 \\
\hline $10.00-11.00$ & 0,68 & 0,72 & 0,78 & 0,92 & 0,97 & 0,68 & 0,96 \\
\hline $11.00-12.00$ & 0,77 & 0,78 & 0,81 & 0,59 & 1,10 & 0,86 & 0,98 \\
\hline $12.00-13.00$ & 0,60 & 0,83 & 0,57 & 0,86 & 0,82 & 0,90 & 1,13 \\
\hline $13.00-14.00$ & 0,64 & 0,84 & 0,63 & 0,82 & 0,98 & 0,79 & 0,64 \\
\hline $14.00-15.00$ & 0,74 & 0,88 & 0,63 & 0,64 & 0,85 & 0,84 & 0,52 \\
\hline $15.00-16.00$ & 0,61 & 0,79 & 0,69 & 0,45 & 0,88 & 0,58 & 0,72 \\
\hline $16.00-17.00$ & 0,63 & 0,71 & 0,71 & 0,57 & 0,87 & 0,58 & 0,79 \\
\hline
\end{tabular}

Sumber: Analisis, 2020

\section{Densitas Pos T2 (V/C)}

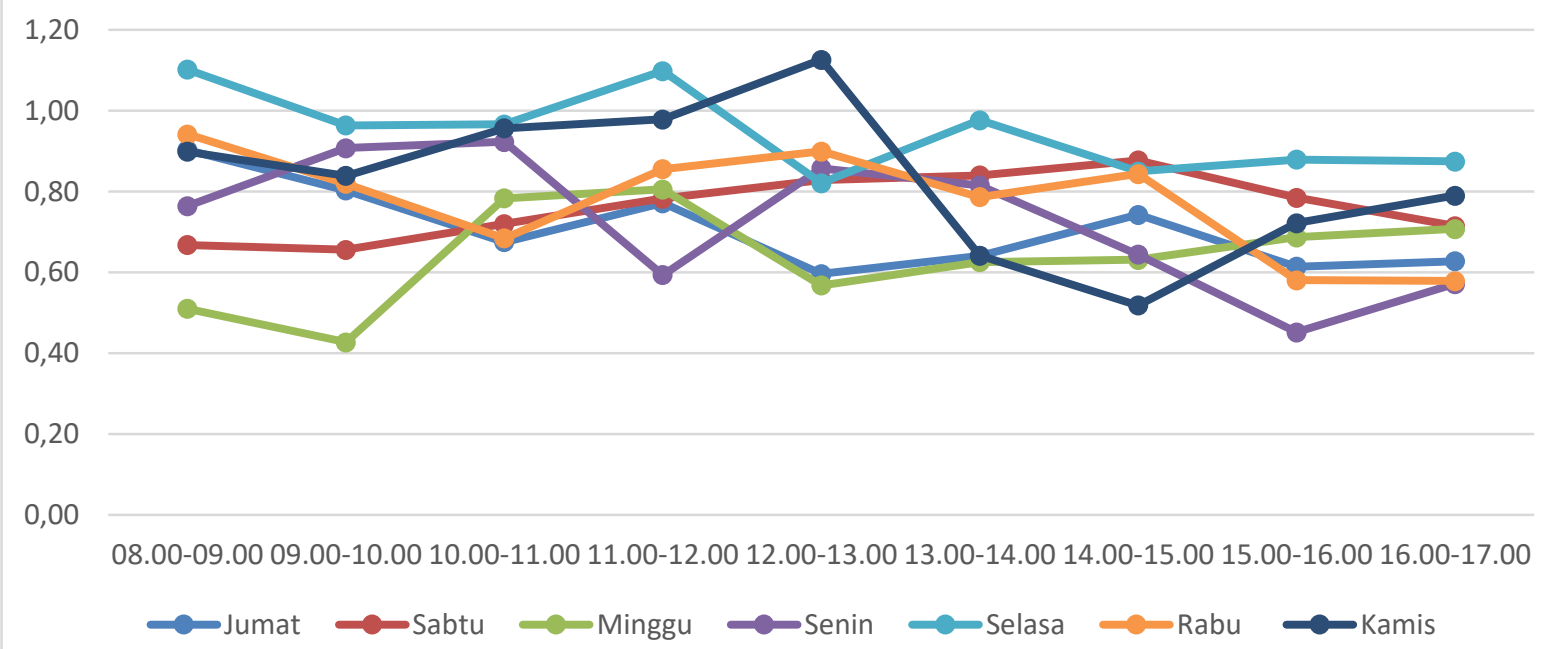

Gambar 10. Grafik Densitas Pos T2 (V/C)

Sumber : Analisis, 2020

Tabel 18. Level of Service Pos T2 (LOS)

\begin{tabular}{|c|c|c|c|c|c|c|c|}
\hline Waktu & Jumat & Sabtu & Minggu & Senin & Selasa & Rabu & Kamis \\
\hline $08.00-09.00$ & D & B & A & C & F & E & D \\
\hline $09.00-10.00$ & C & B & A & E & E & D & D \\
\hline $10.00-11.00$ & C & C & C & E & E & B & E \\
\hline $11.00-12.00$ & C & C & D & A & F & D & E \\
\hline $12.00-13.00$ & B & D & A & D & D & D & F \\
\hline $13.00-14.00$ & B & D & B & D & E & C & B \\
\hline $14.00-15.00$ & C & D & B & B & D & D & A \\
\hline $15.00-16.00$ & B & C & B & A & D & A & C \\
\hline $16.00-17.00$ & B & C & C & A & D & A & C \\
\hline
\end{tabular}

Sumber : Analisis, 2020 


\section{Kesimpulan}

\section{PENUTUP}

Dari hasil analisis kinerja Jalan Adhyaksa Kota Banjarmasin dengan menggunakan perbandingan volume lalu lintas dengan kapasitas akan didapatkan derajat kejenuhan yang akan menunjukkan tingkat pelayanan ruas jalan Adhyaksa dan dapat disimpulkan sebagai berikut:

a. Hari Jumat, 29 November 2019

- Volume puncak pada titik 1 (T2) terjadi pada pukul 08.00 - 09.00 Wita sebesar 1877 SMP/Jam. Tingkat pelayanan jalan adalah F dengan nilai DS sebesar 1,02, dimana karakteristik lalu lintasnya menunjukkan: Arus terhambat, kecepatan rendah, volume diatas kapasitas, dan sering terjadi kemacetan pada waktu yang cukup lama.

- Volume puncak pada titik 6 (T1) terjadi pada pukul 08.00 - 09.00 Wita sebesar 2563 SMP/Jam. Tingkat pelayanan jalan adalah E dengan nilai DS sebesar 0,90, dimana karakteristik lalu lintasnya menunjukkan: Arus tidak stabil, kecepatan rendah dan berbeda-beda, dan volume mendekati kapasitas.

b. Hari Sabtu, 30 November 2019

- Volume puncak pada titik 1 (T2) terjadi pada pukul 08.00 - 09.00 Wita sebesar 2122 $\mathrm{SMP} / J a m$. Tingkat pelayanan jalan adalah $\mathrm{F}$ dengan nilai DS sebesar 1,15, dimana karakteristik lalu lintasnya menunjukkan: Arus terhambat, kecepatan rendah, volume diatas kapasitas, dan sering terjadi kemacetan pada waktu yang cukup lama.

- Volume puncak pada titik 6 (T1) terjadi pada pukul 08.00 - 09.00 Wita sebesar 1895 SMP/Jam. Tingkat pelayanan jalan adalah B dengan nilai DS sebesar 0,67, dimana karakteristik lalu lintasnya menunjukkan: Arus stabil, kecepatan sedikit terbatas oleh lalu lintas, pengemudi masih dapat bebas dalam memilih kecepatannya.

c. Hari Minggu, 1 Desember 2019

- Volume puncak pada titik 1 (T2) terjadi pada pukul 10.00 - 11.00 Wita sebesar 1759 SMP/Jam. Tingkat pelayanan jalan adalah E dengan nilai DS sebesar 0,95 , dimana karakteristik lalu lintasnya menunjukkan: Arus tidak stabil, kecepatan rendah dan berbeda-beda, dan volume mendekati kapasitas.

- Volume puncak pada titik 6 (T1) terjadi pada pukul 11.00 - 12.00 Wita sebesar 2286 SMP/Jam. Tingkat pelayanan jalan adalah D dengan nilai DS sebesar 0,81 , dimana karakteristik lalu lintasnya menunjukkan: Arus mulai tidak stabil, kecepatan rendah dan berbeda-beda, volume mendekati kapasitas.

d. Hari Senin, 2 Desember 2019

- Volume puncak pada titik 1(T2) terjadi pada pukul 11.00 - 12.00 Wita sebesar 2465 SMP/Jam. Tingkat pelayanan jalan adalah F dengan nilai DS sebesar 1,34, dimana karakteristik lalu lintasnya menunjukkan: Arus yang terhambat, kecepatan rendah, volume diatas kapasitas, sering terjadi kemacetan pada waktu yang cukup lama.

- Volume puncak pada titik 6 (T1) terjadi pada pukul 10.00 - 11.00 Wita sebesar 2619 SMP/Jam. Tingkat pelayanan jalan adalah E dengan nilai DS sebesar 0,92, dimana karakteristik lalu lintasnya menunjukkan: Arus tidak stabil, kecepatan rendah dan berbeda-beda, volume mendekati kapasitas.

e. Hari Selasa, 3 Desember 2019

- Volume puncak pada titik 1 (T2) terjadi pada pukul 13.00 - 14.00 Wita sebesar 2230 SMP/Jam. Tingkat pelayanan jalan adalah $F$ dengan nilai DS sebesar 1,21, dimana karakteristik lalu lintasnya menunjukkan: Arus yang terhambat, kecepatan rendah, volume diatas kapasitas, sering terjadi kemacetan pada waktu yang cukup lama.

- Volume puncak pada titik 6 (T1) terjadi pada pukul 08.00 - 09.00 Wita sebesar 3127 SMP/Jam. Tingkat pelayanan jalan adalah $F$ dengan nilai DS sebesar 1,10 , dimana 
karakteristik lalu lintasnya menunjukkan : Arus yang terhambat, kecepatan rendah, volume diatas kapasitas, sering terjadi kemacetan pada waktu yang cukup lama.

f. Hari Rabu, 04 Desember 2019

- Volume puncak pada titik 1 (T2) terjadi pada pukul 14.00 - 15.00 Wita sebesar 2604 SMP/Jam. Tingkat pelayanan jalan adalah F dengan nilai DS sebesar 1,41, dimana karakteristik lalu lintasnya menunjukkan: Arus yang terhambat, kecepatan rendah, volume diatas kapasitas, sering terjadi kemacetan pada waktu yang cukup lama.

- Volume puncak pada titik 6 (T1) terjadi pada pukul 08.00 - 09.00 Wita sebesar 2673 SMP/Jam. Tingkat pelayanan jalan adalah E dengan nilai DS sebesar 0,94, dimana karakteristik lalu lintasnya menunjukkan: Arus tidak stabil, kecepatan rendah dan berbeda-beda, volume mendekati kapasitas.

g. Hari Kamis, 05 Desember 2019

- Volume puncak Pada titik 1 (T2) terjadi pada pukul 12.00 - 13.00 Wita sebesar 2632 SMP/Jam. Tingkat pelayanan jalan adalah $\mathrm{F}$ dengan nilai DS sebesar 1,43 , dimana karakteristik lalu lintasnya menunjukkan: Arus yang terhambat, kecepatan rendah, volume diatas kapasitas, sering terjadi kemacetan pada waktu yang cukup lama.

- Volume puncak pada titik 6 (T1) terjadi pada pukul 12.00 - 13.00 Wita sebesar 3196 SMP/Jam. Tingkat pelayanan jalan adalah $\mathrm{F}$ dengan nilai DS sebesar 1,13, dimana karakteristik lalu lintasnya menunjukkan: Arus yang terhambat, kecepatan rendah, volume diatas kapasitas, sering terjadi kemacetan pada waktu yang cukup lama.

\section{Ucapan Terimakasih}

Penulis mengucapkan terimakasih kepada kawan-kawan dosen Uniska MAB serta semua pihak yang telah banyak membantu kelancaran dan selesainya penelitian ini.

\section{DAFTAR PUSTAKA}

Anonim (1997), Manual Kapasitas Jalan Indonesia, Jakarta: Direktorat Jenderal Bina Marga, Departemen Pekerjaan Umum RI

Anonim (1994), Highway Capacity Manual, Washington DC: Transportation Research Board, National Research Council

Anonim (2006), Peraturan Menteri Perhubungan Nomor KM 14 Tahun 2006 tentang Manajemen dan Rekayasa Lalu lintas di Jalan, Jakarta: Menteri Perhubungan RI

Anonim (2012), Pedoman Penetapan Fungsi Jalan dan Status Jalan, Departemen Pekerjaan Umum, Jakarta

Anonim (2012), "Rekayasa Lalu Lintas/Kapasitas Jalan", https://id.wikibooks.org/wiki/Rekayasa_Lalu_Lintas/Kapasitas_jalan, diakses pada 8 Desember 2019 pukul 16.41

Hobbs, FD, (1979), Perencanaan dan Teknik Lalu Lintas. Edisi Kedua. Terjemahan Ir. Suprapto TM, Msc, dan Ir. Waldijono, 1995. Jogjakarta: Gadjah Mada University Press.

Morlok, Edward K (1978), Perencanaan Teknik dan Perencanaan Transportasi. Terjemahan Ir. Johan Kelanaputra Hainim, 1984. Jakarta: Erlangga.

(1995), Pengantar teknik dan perencanaan transportasi. Jakarta: Erlangga

Munawar, A, (2006), Manajemen Lalu Lintas Perkotaan, Yogyakarta: Beta Offset

Oglesby, E.K, dan Hicks, R.G. (1988), Teknik Jalan Raya, Jakarta: Penerbit Erlangga

Tamin, O.Z. (1997). perencanaan dan permodelan transportasi. Bandung: Penerbit Tarsito

Wells. G. R. (1993), Rekayasa Lalu Lintas. Jakarta: Penerbit Bharatara 